\title{
Changing Priorities for Strategic Planning from National to Territorial Levels
}

\author{
Henri Dou \\ Emerit Professor ${ }^{a}$, Director ${ }^{b}$, CEO $^{c}$, douhenri@yahoo.fr \\ a Aix Marseille University, Jardin du Pharo, 58 Boulevard Charles Livon, 13007 Marseille, France \\ ${ }^{\mathrm{b}}$ Think Tank CIWORLDWIDE, 93 rue du Rouet 13008 Marseille France \\ ${ }^{\mathrm{c}}$ Matheo Software, 69 rue du Rouet 13008, Marseille, France \\ Philippe Clerc \\ Senior Adviser, International Economic Intelligence unit, p.clerc@ccifrance.fr \\ Chambre de Commerce et d'Industrie (CCI France), 8-10 Rue Pierre Brossolette, \\ 92300 Levallois-Perret, Paris, France
}

\author{
Alain Juillet \\ President, alainjuillet@aol.com
}

French Academy of Economic Intelligence (Académie de l'Intelligence Économique), 4 Place Saint Germain des Prés 75006 Paris France

\begin{abstract}
$\mathrm{T}$ This article deals with the new aspects of Competitive and Strategic Intelligence applied to territorial development. A key place is given to the epigenetics role of information in enabling institutions and people to move toward new visions and new methods of thinking. Territorial security is also examined as well as different contexts in which this intelligence is leveraged and implemented. Competitive and Strategic Intelligence at the territorial level must add to its already well-known methods and tools and consider all the ways to develop

projects linked to the "commons" and thus be well received by the inhabitants. This article also emphasizes the need to explain, demonstrate, and openly present the options for territorial development in order to reach the widest possible consensus. A special note has been added to the introduction, since at the time of writing this paper COVID-19 has acted as a revealer of economic, social, and political life and the challenges the actors of Competitive and Strategic Intelligence may face in applying new approaches and a new vision for its role.
\end{abstract}

Keywords: competitive intelligence; strategic intelligence; territorial development; epigenetics; consensus; archetype; decision making; regional security

Citation: Dou H., Clerc P., Juillet A. (2020) Changing Priorities for Strategic Planning from National to Territorial Levels. Foresight and STI Governance, vol. 14, no 3, pp. 88-99. DOI: 10.17323/2500-2597.2020.3.88.99 


\section{Introduction}

In the report produced by Bernard Carayon [Carayon, 2003], social cohesion was associated with Competitive Intelligence, highlighting the role it should play in the context of a country's economic development. Since that time, the situation has changed considerably and various crises have taken place at the geopolitical, economic, social, and climatic levels. These crises have highlighted the effects of climate change, the fragility of the economic system, an increasingly fractured society, and an international tendency to turn in on oneself. In our earlier twovolume work [Dou et al., 2018], the foundations of a new Economic and Strategic Intelligence, taking into account past errors but also the changes that occur in our environment, are described in detail. Foresight, global security, and the impact of information upon the evolution of individuals and organizations are underlined.

In this context, the objective of this article is to go a little further into the analysis and to position Economic and Strategic Intelligence beyond a simple tool associated with economic growth. Then concepts, methods, and tools to enlighten this new vision are presented, adding a new dimension to Competitive and Strategic Intelligence and projecting it into a dimension more suited to helping us understand and, if possible, to anticipate the global changes currently underway.

An increasing number of terms such as "innovative nation", "smart territories", "territorial intelligence", "smart development", "sustainable development", and so on are used frequently. However, what in fact do they cover and how can we have an overall vision allowing national and local actors to harmonize actions and stimulate a constructive dynamic? This is what we are going to sketch out in order to open avenues for reflection and action. It is from a set of territories, each of which, with their specificities, their potentials, and the women and men who drive them, that the crucible foundation of the Nation ${ }^{1}$ was formed [Dou, 2018c]. Although the term territory is widely used, its definition and its outline give rise to variable definitions, which are often contradictory, sometimes even opposable when one places oneself solely at the level of territorial competitiveness.

In this study we are going to defend an entirely different position, where the notion of territorial competitiveness, in the same Nation, must give way to a specific harmonization of skills to find the drivers of national competitiveness within a national synergy driven by the state.

\section{Special Note}

At the time of writing this paper, France, like many European countries, was fighting against COVID-19.
The sudden appearance of this pandemic, an invisible enemy, has upset geopolitical, political, economic, and social behavior. In such a framework, Competitive and Strategic Intelligence takes on another dimension. It allows those who practice it to shed light on political errors as well as hasty and of ten dogmatic decision-making. It also highlights the lack of foresight, which has been repeatedly stressed by the authors of this text, or the use of this to consolidate economic and lucrative positions at the expense of citizens' health. In this context, the "commons" which were reinforced in the period of the Thirty Glorious Years (1945-1975) made it possible to secure populations by ensuring they receive both psychological and material comfort. However, the development of neo-liberalism which followed these years placed profit at the center of the concerns of political and economic actors. Thus inequalities have increased and the "commons," instead of being consolidated for the benefit of all, have been redefined so that certain people are able to take advantage of them. Think, for example, about the management of water, energy, agricultural production, industrial desertification in developed countries and health. This blindness has made us lose sight of the fact that health is a common good. The rationalization of costs and the maximization of profits have led it to become a commodity and one sees this in the decrease in hospital endowments, the scarcity of doctors in isolated areas, and the almost total dependence upon the active components of drugs.

The current pandemic is shaking up ideologies and reminding us that nobody is safe from the outbreaks of a virus and that neither the accumulated profits nor the constant progression of "soft trade" constitute a sufficient protective barrier, especially when a vaccine or medical treatments do not exist. The international shadow theater is crumbling, alliances are evolving and reshaping in a chaotic progression; what will be left at the end of this episode? Certainly changes in behavior and above all, it is to be hoped, greater security for the "commons" among which are water, energy, food, and health. Which constitutes the largest part? The authors propose water because it is directly linked to health and energy and therefore is directly linked to better security and the acceptable maintenance of living conditions.

It is in this context that a new Competitive and Strategic Intelligence must be developed to analyze the constraints, stresses, and unexpected threats that will impact communities. It must contribute to building local resilience allowing for an acceptable response to the "predicament" [Dou et al., 2020] and helping create a new and ethical governance. In Competitive Intelligence, the concept of global security has been developed over time adding a holistic vi-

Henri Dou, Conférence inaugurale, Colloque International L’Intelligence Compétitive des Entreprise et des Territoires, 1 - 2 Décembre 2018, Université Mouloud Mammeri , Tizi-Ouzou, Algérie. 
sion to this domain. However, COVID-19 is, in some respects, reshaping our mind and our vision. For instance, when we look at the link between competitive intelligence and what is called the collapsology (from the word collapse) [Dou et al., 2019], most of scholars interested in this field pointed out the need to introduce this perspective to the entire analysis [Kyrou, Rumpala, 2019; Darbellay, 2019]. But even doing so, who would have imagined the unthinkable: the pandemic and COVID-19!

\section{From Economic Competition to Territorial Development}

In most of its definitions Competitive and Strategic Intelligence is seen as a tool to improve the competitiveness of companies and to enhance their economic impact upon their own business. If the key role of information is underlined in most of these approaches, there are nevertheless some aspects of Competitive and Strategic Intelligence that are dynamic. Numerous voices point out that looking only to the economic growth may lead to a dead end. There are several points which support this view, such as:

- the gap between different classes of society is widening [Greenwood, Hinings, 1993; Hanushek et al., 2019]

- climate change will exacerbate various stresses among the inhabitants, nations, and companies [Staffell, Pfenninger, 2018; Curtis et al., 2017]

- new menaces, among them cyber risks, terrorism, plagues, and influence [Duarte, 2020]

- technological changes impact the general profiles of employment [Franken, Wattenberg, 2019]

- new ways of life more or less linked to ecology begin to appear [Loiseau et al., 2016]

- confidence in political decision makers decreases [LeVeck, Narang, 2017]

- co-construction of local projects are increasingly necessary [Froese, Mevissen, 2020]

- a new form of competition develops between regions (even in the same state) and even city centers are opposed to the peripheries [Hauswedell et al., 2019; Hassink et al., 2019].

In this context, we believe that Competitive and Strategic Intelligence cannot be absent from this environment and if we want to enlarge its impact upon society, new forms of action are necessary. This is one of the reasons why France adopted the law NOTRe ${ }^{2}$, which has given the regions the task of developing competitive regional intelligence to make all the local stakeholders in development able to use these methods and tools to encourage local development. At the same time, this law increases the power of met- ropolitan areas compared to the rest of the region, which, if we are not careful, will lead to an increase in territorial inequalities [Dumont, 2017]. We believe, however, that the development of local Competitive and Strategic Intelligence can be a catalyst for a new vision and objectives that will help reduce the differences introduced by this law. In this framework, a point which is very important is the defense of the "commons" which often are not well perceived by the local people. The inclusion of the defense of the commons and well-being into the framework of Competitive Territorial Intelligence will create new incentives and popularize Competitive and Strategic Intelligence among civilians.

\section{Propagating Competitive Territorial Intelligence among Citizens}

Currently, many people confuse territorial attractiveness and territorial specialization with competition between territories. This does not make much sense within the same country, because weakening one territory over another, concentrating all facilities in metropolises without worrying about the interstitial spaces between them may lead to a negative outcome. We are therefore going to plead for another vision, for a harmonious integration of the territories into a national whole co-constructed by all the actors.

\section{The foundations of competition and capitalist society} In a remarkable book L'Entraide une Autre Loi de la Jungle (Mutual Aid, Another Law of the Jungle), Pablo Servigne and Gauthier Chapelle [Servigne, Chapelle, 2017] highlight the shift that has led us to consider nature as hostile and generating competition without pity, while the observation of it shows us on the contrary that mutual aid between species, cooperation, are in order while competition appears only in brief moments. The point of view highlighting competition as a goal has been described by sociologist Alain Caillé as "the axiomatic of interest" [Caillé, 2016]. We can also refer to the work of Jérôme Lamy [Lamy, 2014] on "liberal sources of biopolitics" where he defines liberalism as a "technology of power" and underlines that "The historical philosophy of Michel Foucault makes it possible to point out, behind the political practices of liberalism, the enslavement of the greatest number to market forces ... Liberalism is first of all a conservatism..." [Lamy, 2012].

\section{Harmony through thoughtful mutual aid}

As Pablo Servigne and Gauthier Chapelle [Servigne, Chapelle, 2017] point out, more and more research and scientific results clearly show that competition is no longer an end in itself and that other paths of development are possible, even with the natural world.

\footnotetext{
${ }^{2}$ Available at: https://www.cohesion-territoires.gouv.fr/loi-portant-sur-la-nouvelle-organisation-territoriale-de-la-republique-notre, accessed 15.05.2020.
} 
This is why "the themes of competition, the fight for life, the cumulative transmission of benefits and the elimination of the less able ... To justify a laissez faire .." are strongly contested by recent advances taking place in the field of cognitive sciences. Seen in this regard, the work [Blanchy, 2013] stipulates that "The myth of the separation between nature and culture is now shaken, and this has strong implications for the economic models that we can develop, allowing development in new, innovative and fruitful settings." [Ibid.]

This, transposed onto the field of territorial development, calls for the development of homogeneous visions embedded in the local culture, that are widely accepted and will constitute a motivation contributing largely to success. The distinction between nature and culture has led, for example, Bruno Latour [Latour, 1991] to indicate that "mediation must be recognized in the common production of societies and natures. Language, discourse, are another mediator between nature and society, they contribute to the production of hybrid objects that are both real, discursive and social." Thus, in the context of the choice of developments, of the visions to be appropriated by a territory, mediation, explanation, and the search for consensus will be precious allies, inseparable from success. ${ }^{3}$ Culture must also be considered in all international collaborations, but it is also a vector of penetration and influence that should not be overlooked [Clerc, 2008].

\section{The Creation of a Regional Motivation}

If in mathematics two plus two equals four, it is not the same when energies accumulate. The work of a group, its creativity, is generally stronger than that of its members individually. But, for this synergy, this "alchemy" to occur, we will have to meet certain conditions, break mental archetypes and analyze in more detail the mechanisms of collaboration and leave behind the often reductive vision of current models.

\section{Epigenetics of organizations}

In the book "The economic intelligence of the future" [Dou et al., 2018], we underlined the importance of these analyses, and why, to develop a vision in line with the future and the prospective, the ways of thinking must be reviewed. This leads us to better understand the evolution of organizations, not from a conventional and classical point of view, but from the point of view of their epigenetics. Henri Dou in an article entitled "From the Metabolism of Information to Economic Intelligence" [Dou, 2018], highlights that an organization, like a human being, can, throughout its existence, act on its "DNA junk" 4 to partially mobilize it and thus change its state. This mutation, which is partially transmissible, is found, as Joël de Rosnay [Rosnay, 2018] points out, within human groups and organizations. This faculty to transform, by its actions, its way of being, its way of life, and to think as part of its genetic characters, can by analogy be applied to a region, a company, and a group of companies. Thus, within these, the archetypes which prevent them from evolving, we then speak of "organizational templates" [Greenwood, Hinings, 1993], will fade and the group concerned will mutate and evolve. What seemed impossible will become achievable and the vision of the past will be replaced by that of the future. In the context of the influence of holistic information retrieval followed by an analysis through a critical thinking approach, a few works indicate that such practice will produce changes in the individual ability to handle information and to achieve a sort of serendipity. This direction is pointed out by [Ackerman,1988; Major, Kozlowski, 1997; Hirth, 1996], and more recently by [Lynch, Stretesky, 2017].

\section{Application at regional level}

One of the driving forces at an organization, in a region, is the information from which we will create "intelligence for action." It is therefore necessary to take into account and analyze how an institution is informed and how this information is metabolized. As Henri Dou [Dou, 2018] points out, this brings us back to the role of the "information function within an organization and, among other things, within companies. Indeed, it is from this that we will organize the creation of knowledge for action, from analyses and recommendations, applied to the strategic objectives of a company. There are, however, two ways to do this. The first, which is in our opinion the worst, is to acquire information in a completely external way without being able to intervene in its content, its coverage, and the successive iterations during which we learn to be better informed, formulate, and create a serendipity which in many cases will create a difference. The second deals with what we call the internal endogenous information function of the company, which creates a climate of curiosity and astonishment that in turn facilitates decision-making to be permanently and endogenously reinforced. Of course not all the information can be made available by the simple fact of the exploitation of various sources of information at the organization, but if a large part of it is acquired by the effort of the whole institution, we will then create the "critical memes" ${ }^{5}$ which will encourage its transformation. In addition, fueled by

\footnotetext{
3 For example in South Korea, the determination of the strategic technologies to be developed brought into play a "Delphi" (known as Korean Delphi) of more than 25,000 national experts. This has greatly contributed to the creation of a national consensus on the objectives to be achieved.

${ }^{4}$ Any DNA fragment present between DNA coding sequences. This DNA may or may not encode regulatory sequences: http://dictionnaire.sensagent.leparisien.fr/Junk-ADN/fr-fr/, accessed 18.02.2020.

The "méme" is a cultural equivalent of the gene. "A unit of information contained in a brain and exchangeable within a society" [Dawkins, 1976].
} 
a collective effort to access information and analysis, the archetypes acquired during the past existence of the company or of the human group concerned may be changed, the "non-human"6 world, that is to say the interface of the company with the outside world, will become more understandable and will generate new behaviors. ${ }^{7}$

\section{Towards a New Territorial Intelligence}

This analysis leads to the need to revisit Territorial Intelligence at different levels. These will concern, first, common goods (commons), among other things in the sense of preserving the environment [Baaziz et al., 2017, Dou, Leveillé, 2015]. The concept of the "commons" is fundamental if we want to achieve sustainable and harmonious territorial development. It is only necessary to recall the quotation from Peter Linebaugh [Linebaugh, 2010] "the enclosure movement in England is one of these concrete universals, like the triangular slave market, witches brought to the stake, Irish famine, or the massacre of the Indian nations, which make it possible to define the crime of modernism, each time limited in time and space, but always going beyond the specific and likely to come back to the fore" and Elinor Olstrom's research [Olstrom, 1990, 2012] whose work on the management of "commons" won her the Nobel Prize in Economics in 2009 [Le Crosnier, 2012].

Secondly, there is the need to not use the name of specialization or intelligence (in the sense of "smart development") in intra-regional competition, which does not allow in most cases for creating a positive synergy between the actors. Similarly, it is necessary to avoid (or at least limit) the concentrations of wealth on specific poles in a region, which is to the detriment of the rest of the region. Indeed, the new economy, if it creates wealth, has the effect of concentrating it on the one hand and on the other, limiting its diffusion to the periphery. We can consult on this subject in the work of Laurent Davezies and Thierry Pech [Davezies, Pech, 2014]. We thus find in the concepts of cooperation and mutual aid, a positive complementarity and a mutation catalyst that has as a starting point the individualization of the people involved in the group in the sense of Simondon [Neves, 2011; Chabot, 2013], a true philosopher of information which in his informational ontology, presents a radically new materialism that stands to change contemporary debates surrounding issues related to information, communication, and technology [Iliadis, 2013].

\section{The role of Competitive and Strategic Intelligence}

Economic Intelligence is rightly seen as a dynamic element for positive change. The positioning of re- gional strengths and weaknesses in a national or international environment plays a major role, but for this it is necessary to acquire the necessary information, share it, and from this, develop a clear vision of regional development. What can we do (implied together!)? This question challenges both ideas and pressures of all kinds, psychological and material, from the regional past. If common history cements women and men, it should not be an impediment to development by freezing positions. It is in this sense that acquiring new forms of thought, having a clear vision of geopolitical developments, and developing a "endogenous information" function will quickly lead to the monopolization of "dormant energies" [Dou et al., 2018]. We thus create by analogy with the monopolization of certain genes in the sense of the epigenetics of human beings, new behaviors that are partially transmissible and reversible [Berger et al., 2009]. This reversibility requires the continuous application of Competitive and Strategic Intelligence. It is clear that all the methods and tools of Competitive and Strategic Intelligence are still usable [Revel, 2015], but it is necessary to broaden the horizon of the latter by using foresight, collective intelligence, and strategy [Dou et al., 2018] as well as the development of regional spheres of influence driving the exports [D'Aveni, 2012]. In the same way, various authors such as Madureira and al. [Madureira et al. 2019] suggest that

"The CI model, however, has not evolved to address evolving intelligence needs, highlighting an opportunity for further research on how to fit for purpose the CI process itself ..." and suggest that the "Design Thinking mindset and process has potential for the application to the CI model, improving efficiency both in the overall process, at each stage and in CI." This clearly seconds the vision for a holistic effective change to the Competitive Intelligence approach. The various steps of Design Thinking [Micheli et al., 2019] are similar to the De Bono [Göçmen, Coşkun, 2019] solving problem system.

\section{Create a national dynamic}

We have so far only considered the region, but the nation, the sum of all regions and the different communities that make them up, can facilitate this new approach. This can be achieved by setting up a Competitive and Strategic Intelligence policy at the national level without repeating the mistakes of the past generally committed locally or by third-party examples. This policy must obviously be based on technical elements and supports, on compendiums and repositories [Revel, 2015], but if it is limited only to this "material" aspect of things, we will quickly see its failure. In the context of this national policy, the

\footnotetext{
${ }^{6}$ The "non-human" world is taken here in the sense of Simondon (opus cited), in particular with the technological environment which surrounds us and is constantly evolving.

Available at: https://www.franceculture.fr/emissions/les-nouveaux-chemins-de-la-connaissance/gilbert-simondon-14-du-mode-d-existence-d-un, accessed 15.03.2020.
} 
common good, shared between the actors of the territory and developed by a dynamic economy must be constantly reinforced. In this sense, cooperative actions, individual and collective contributions, and the creativity of individuals [Verlaeten, 2010] must not be considered obstacles, but constructive values. Thus, competition must be replaced by cooperation, directionality often exercised in a "top down" manner must in many cases be replaced by a "bottom up" approach, the difficulty resting upon the organization of new participatory methods. Finally, the development of a region must primarily have as its objective the growth of the national economy, but also, and this is often forgotten, the increase in the well-being of the individuals that make it up.

\section{Territorial Security}

Territorial security today is an important element for residents and businesses. There are many aspects, from physical security to abusive approaches (telephone marketing or solicitations via the Internet) and the cybersecurity of companies. It is therefore important, within the framework of Competitive and Strategic Intelligence, that these aspects are considered in order to give regional decision-makers the necessary information and also to explain good behaviors to avoid being victims of these embezzlement schemes.

\section{Physical security}

The state, within the framework of the national plan of Economic Intelligence, set up organizations intended for the representatives of the police forces, mainly those of the "gendarmerie." The gendarmes, who are in contact with the local population and who crisscross the territory, are able both to inform and also collect useful information to ensure general protection. In the context of business protection, at the territorial level, more than $80 \%$ of SMEs and very small businesses are located in the area of gendarmerie's competence in matters of public security. ${ }^{8}$ Based on this territorial network, the gendarmerie has economic security and business protection referents (SECOPE) in each region, in each department, and in each of the specialized gendarmerie groups. The national gendarmerie has nearly 200 economic intelligence advisers. All of these protective actions are part of the economic security plan ${ }^{9}$ developed in France at the national and regional level. This service (Strategic Information and Economic Security
(SISSE)) manages a network of delegates responsible for coordinating the implementation of the economic security policy.

\section{Information and good behavior}

The Cybermalveillance.gouv.fr service ${ }^{10}$ is responsible for helping businesses, communities, and individuals strengthen their own cybersecurity by informing them about current digital threats and explaining the correct behavior to follow. For example, the website of this service informs the public about threats that may appear during updates to computer operating systems, how to protect mobile devices (smart phones, tablets), how to manage passwords, security on social networks, how to learn to separate your domestic and professional uses, and why and how to manage your computer backups properly. This is just an example of general public information. The following figure shows the interactive characteristics of the cyber malware information site.

\section{Economic interference}

In this context, the DGSI (Directorate General of Internal Security) provides companies with "flashes" in the form of electronic bulletins. ${ }^{11}$ These "flashes" indicate actions of economic interference of which French companies are regularly victims. Designed to illustrate the diversity of situations that companies are likely to face, it is at your disposal to assist you in propogating an internal security culture.

\section{Practical Methods of Implementation}

Implementing such a policy is not easy. At the regional level, a concentration of actors is essential in order to analyze the existing potential, whatever its nature (the choices of areas to be developed will be made after). This done, it will be necessary to facilitate the decision and analysis by setting up an efficient information function, localized or networked. The goal is ultimately to allow the best decision-making, but also a clear explanation of it [Latour, 1991] so that a consensus is created. Once the decision has been made, the methods of achieving it will have to be analyzed critically in order to see to what extent regional forces are sufficient to achieve the objective, if possible, a motivation will be created to facilitate action. If the necessary potential to achieve the objectives is not available locally, ${ }^{12}$ it will be necessary to see if these skills are transferable or exploitable in a delocalized way. If this is impossible, more realistic objectives

\footnotetext{
${ }^{8}$ Available at: https://www.gendarmerie.interieur.gouv.fr/Nos-conseils2/Pour-les-professionnels/Presentation-de-la-chaine-des-referents-Securiteeconomique-et-protection-des-entreprises-SECOPE, accessed 15.05.2020.

9 Available at: https://sisse.entreprises.gouv.fr/fr, accessed 04.05.2020.

${ }^{10}$ Available at: https://www.cybermalveillance.gouv.fr/, accessed 14.01.2020.

${ }^{11}$ Available at: https://www.globalsecurity.org/intell/world/france/dgsi.htm, accessed 16.04.2020.

${ }^{12} \mathrm{Be}$ careful, because in many cases we will see a certain number of people, even companies or institutions claiming to be experts in all fields appearing under the concept of multidisciplinarity. As Alain Caillé [Caillé, 2018] points out, "The false ideal of multidisciplinarity is the perfect complement to the academic triumph of hyperspecialization and disciplinary fragmentation." It is therefore necessary to use recognized experts to validate the choices so as not to leave a certain number of makers and "illusionists" to grab the attention of decision-makers.
} 
will have to be selected. But this is far from being enough, we will have to somehow master the process of achieving objectives. For this, a contract is the best way to do it.

Contractualizing actions, continuously monitoring them, and modifying part of the objective if necessary are the best way to manage regional objectives dynamically. This means that the monitoring of operations should not be limited to the recording of interim reports, but to a real analysis of the latter and, if necessary, to reduce or stop the funds allocated in the worst cases. Managing projects in a democracy is a difficult task, but the good governance of it is the best critical factor of success [Leese, 2017].

Here we touch upon a sensitive point concerning innovation. An innovation is the transformation of ideals and skills often acquired thanks to state funding into profitable products. This regional implementation also means that actors that have different objectives, for example associations, academics, and industrialists, will be brought to work together. The management of such groups is a critical task that must be mastered, the common denominator being action to improve the public good. For example, within universities, it is necessary to develop the RSR (Social Responsibility for Research) [Dou, 2010]. For industrialists, they must not consider that discussion with academics a waste of time. Politicians must put into place the events and structures that will encourage contact between various parties, but they must also understand the fundamental role played by Competitive and Strategic Intelligence to federate the actors and create a regional dynamic.

Regional development brings into play both the practices of institutions and people based on archetypes acquired throughout their histories. This calls for collective action and responsibility [Nonaka et al., 2000]. If, as Simondon points out [Neves, 2011], the individual is in permanent tension because of its relationship with change, it will be necessary to reinforce the collective action using different methods than the conventional ones applied today, which means one must explain, demonstrate, and try to achieve a wide consensus.

The development of biomedical research is interesting especially amid COVID-19. Let us quickly return to the concept of innovation. Innovation leads, thanks to state funding, to the creation of know-how and knowledge in public research laboratories. This knowledge will then be used to help create marketable products. This process is generally carried out through start-ups, which, when they are successful, are bought by large pharmaceutical companies, often foreign (this is the actual French model). However, since the creation of knowledge is carried out thanks to our taxes, since it is the state that finances such
Figure 1. Screen capture of one of the domains covered by the cyberbullying site

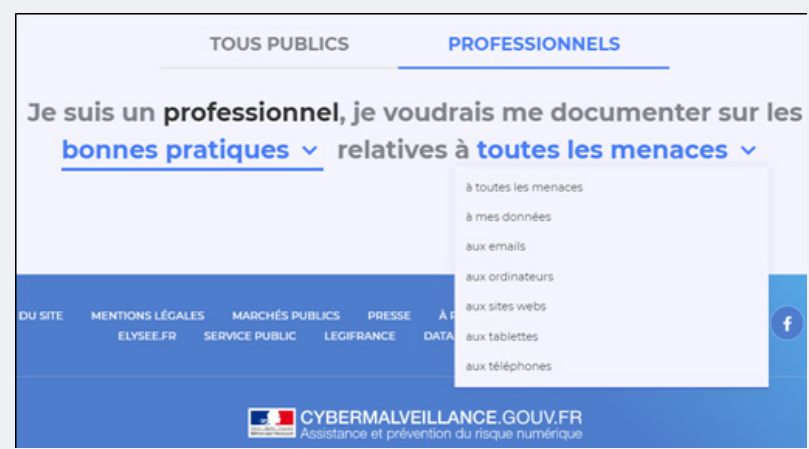

Translation: I am a professional, I would like to document myself on good practices relating to all threats. Choice: to all the threats, to my data, to emails, to computers, to websites, to tablets, to phones.

Source: https://www.cybermalveillance.gouv.fr/bonnes-pratiques, ac cessed: 14.01.2020.

projects, we must ask to ourselves a fundamental question: is public research (at least its results) a public good? Does it fall within what is commonly known as the commons [Dou et al., 2020]? The answer to this question is essential because if it is affirmative, it must lead to a different marketing model [Holloway, Herder, 2019]. This is a hot topic if we consider the discovery and production of a vaccine against COVID-19.

\section{Examples of Implementation}

Increasingly, the action of civil society in collaboration with or without regional political bodies allows for the development of innovative achievements or structures. Success in projects comes mainly from the feasibility of the latter according to local capacities and knowledge, but also from the broad consensus which supports them. The three following examples will illustrate this point.

\section{Luc sur Aude's citizen solar park}

Luc sur Aude is a small French town located in the southwest of France, where an event took place within the framework of territorial development that is particularly meaningful. For almost 10 years, a photovoltaic park project has been under study in the scrubland north of Luc-sur-Aude. Various promoters presented themselves without their projects succeeding. If the operation is profitable for industrialists, why should it not be profitable for a community? From this observation was born the citizen solar park project, which is energetically sustainable, humanly feasible, and economically profitable. ${ }^{13}$ Thus, in 2018, "In the Aude, a photovoltaic power plant financed and managed by the inhabitants was developed.

${ }^{13}$ Available at: https://www.luc-sur-aude.fr/projets/parc-photovoltaique/, accessed 12.02.2020. 
1,2,3 Soleil is the first French citizen solar park built thanks to crowdfunding: 286 individuals, residents of the village of Luc-sur-Aude or its surroundings, have invested in this power station which will produce 320,000 kilowatt hours per year, i.e. the consumption (excluding heating) of the Luçois" [Rollot, 2018]. This is how citizens of a rural village in the south of France took their destiny and energy autonomy in hand.

"For several months in 2018, the Luc-sur-Aude photovoltaic power station, near Limoux, has been producing electricity with the financial participation of its inhabitants who have become shareholders in the installation. The project had the honor of the visit of the president of the region, who came to visit the first participative photovoltaic park of municipal inspiration in France. We wanted a project sized to cover the electricity needs of our town while keeping the added value thanks to citizen shareholding, explains the mayor of the town, who will have taken eight years to make this dream come true."

As the BFM Business station pointed out during a TV broadcast on June 12, 2018 $8^{14}$ : the main lessons to be learned from the success of this project corroborate all the aspects related to territorial development presented above. The shared vision, mutual aid, continuity in action, consensus, the participation of local political bodies, and the financial participation of local actors cemented the consensus. This success also underlines the fact that technical solutions exist and that many of them can be implemented within the framework of shared local will.

\section{The Territorial Poles of Economic Development (PTDE)}

Like the competitiveness clusters developed in France since 2005, various reflections have led to the emergence of the concept of PTDE (Territorial Poles for Economic Development). A definition was developed by the ESS laboratory, ${ }^{15}$ "A territorial pole of economic development (PTDE) is a grouping, on a given territory, of initiatives, companies, and networks of the social and solidarity economy associated with SME managers, local authorities, research centers, and training organizations, which implements a common and continuous strategy of cooperation and mutualization for the service of innovative economic projects of sustainable local development" [Matray, Poisat, 2014]. Indeed, territorial development projects are based in part on creating innovative achievements by:

- the capacity of actors to create and develop through deliberation in a public space [Habermas, 1978]

- collective intelligence [Heurgon, 2006]

- mobilizing all stakeholders, including the university [Goujon et al., 2011, Dou, 2016]

- the training organizations
We can thus see that beyond all kinds of blueprints, often virtual directives, we can hardly achieve anything without the motivation of the actors, a wellreasoned explanation of the projects, and the active participation of civil society.

\section{The experience of the Var region}

The Provence Alpes Côte d`Azur region includes several departments including Var. It is wedged between Marseille metropolis and Nice Sophia Antipolis. In this configuration, the Var must find a new identity that will allow it to implement its own development between two entities (Marseille and Nice) in which is concentrated a large part of all the resources of the Sud Provence Alpes Côte d>Azur region. Under these conditions, two facts emerged: a rise in the power of civil society and a division of the department into territories having a social, cultural, economic, and geographic identity. The geographic space is bounded by a 20 -minute drive. The economic, cultural, and social aspects have been carefully examined so that the territories are homogeneous. Eight territories were thus created after surveys, studies, INSEE data, and consultations of the concerned municipalities. This is how the 153 Mayors of the Var's municipalities have joined this approach, all political positions combined. Unlike the Alpes Maritimes and Bouches du Rhône, which have a metropolitan approach, Var is part of a concerted territorial approach. The Var territories - so-called Strong Points (PFs) are as follows:

- Aire Dracénoise PF: urban economic and nature center

- Coeur du Var PF: nature and development

- Fayence PF: hilltop villages and green tourism

- Gulf of Saint-Tropez PF: international tourism

- Haut-Var Verdon PF: nature, escape, and competitiveness

- Provence Méditerranée PF: metropolis, competitiveness, and sea

- Provence Verte PF: historical heritage and development

- Var Esterel PF: economic dynamism and living heritage

It was upon the basis of the dynamics of these territories that the concept of a contractual project over a period of three years was born. The objective was to develop a project for each territory, three types of which may be involved:

- Local actions (services, equipment, and activities),

\footnotetext{
${ }^{14}$ Available at: https://bfmbusiness.bfmtv.com/entreprise/comment-ce-village-occitan-a-finance-sa-propre-centrale-solaire-1468552.html (accessed 07.04.2020)

${ }^{15}$ Available at: www.lelabo-ess.org (accessed 19.05.2020)
} 
- Structuring actions (networking and interconnection with neighboring territories), for example, broadband, physical mobility, etc.

- Flagship projects to enhance the reputation, image, enhancement, and attractiveness of the territory.

In each case, it is necessary to consult the public and private sectors whenever possible and to make extensive use of innovations from civil society based on calls for projects. This includes actions aimed at developing tourism, new concepts for activity zones, open work spaces, the creation of labels for products from the region (it is not just wine that is concerned), local gastronomy, assistance to the elderly, and so on. We can also note, in the same vein, the creation of a local television channel: Var Azur.

There is thus a double entry at the territorial level: projects from elected politicians taking into account major facilities or structuring projects, but also an entry from civil society through the intermediary of the calls for projects. The goal is both efficiency and consensus. An innovative aspect of this development system is the contract. Each of the projects is linked by a three-year contract to the entity funding the project (generally the Departmental or Regional Council). This contractualization makes it possible to monitor the project both in terms of timing or implementation as well as in financial terms. The project contract then becomes an effective engine of development. We are thus moving towards a culture of results. To further increase the cohesion and synergy, the Territorial Development Houses (MDT) were developed in which civil society and the human dimension are directly concerned. The MDTs will also play the role of a territorial observatory: local project files are evaluated there, the link with the population will be strengthened by various services, and the local economic fabric will be able to be energized both by contacts and communication.

In parallel with this territorial development, civil society and more particularly companies organize themselves independently of political power or of institutions such as Chambers of Commerce and Industry. This is how the "Var Business Parliament"16 was launched by personal initiatives. It was created so that major decisions are not based solely on elected politicians so that the voice of civil society is taken into account.

The Var Business Parliament, an original initiative in France, has become a promoter of ideas, projects, and innovation. It operates on the basis of commissions and we can cite an example from the blog of the Var Business Parliament:

"Nearly 400 actors from the Var business world participated in the plenary session of the Var Business Parliament. On the program, the examination of $8 \mathrm{mo}-$ tions relating to the maritime economy, the circular economy, and the advisability of a territorial branding were proposed.

It is a great demonstration of the collective intelligence to which we are entitled. In turn, the committee leaders, after having showcased the fruit of the work carried out over several months, presented concrete motions, based on field reflections for a vote. For a more in-depth description of the functioning and role of this parliament, you can consult the blog of Patrick Heintz. ${ }^{17}$ A quote from the author of this blog sums up the question well:

"There are in the almost 60,000 companies that make up the economic fabric of our territory, treasures of experience, imagination, know-how that can contribute to significantly improving our economic environment by working more together on common strategies, by cooperating and mutualizing better, by exchanging more on practices, methods, by sharing know-how, services, certain tools, means, networks. The Var Business Parliament can be the place where this collective awareness occurs, where these new relationships are formed and where the economic world makes its voice heard."

\section{Conclusion}

Territorial development requires, in addition to the methods and tools of Competitive and Strategic Intelligence, a strong mobilization of local actors because the results obtained at the territorial level are more easily perceived by the whole population. As a result, the time constants necessary for carrying out the projects will be shorter, so any delay or any longterm project must be justified. In addition, at the territorial level, the search for synergy between the actors, the complementarity of skills, and consensus must be sought. As pointed out by Yun and al. [Yun and al., 2020] "The competitive intelligence experts and scholars have published a large number of theoretical knowledge in methodology.... The mastery of any knowledge could not be completed in one time. It needs to go through many cycles of 'reading, seeing, listening and thinking. We all need to verify our knowledge in specific problems to truly understand it, thus our understanding will go further." The objective is to create a change of mentality, to rely upon studies involving the psychology of stakeholders to engage them in a renewal of mental archetypes which often impede the situation and block development. This calls for territorial engineering leaving more room for human sciences compared to strictly technological considerations. For this, the history and local culture or cultures must be analyzed and often used as leverage to monopolize energies, which is the case under various conditions such as NATO operations [Yankov, 2019] as well as in economic development [Kafka et al., 2020], tourism [Alazaizeh et al., 2019], or even organizations [Hashemi, 2016]. Finally, civil society is directly concerned with territorial development and we must set up the participative modali-

\footnotetext{
${ }^{16}$ Available at: https://www.var.cci.fr/content/le-parlement-varois-des-entreprises-les-commissions (accessed 11.03.2020)

${ }^{17}$ Available at: http://patrick-heintz.over-blog.com/ (accessed 09.02.2020)
} 
ties of this when defining a vision and the projects that result from them. Furthermore, this must be the case throughout their realization and analysis and the judgment of the obtained results. This is one of the most important conditions for success, because in the 21 st century in France, we can no longer be content with an election every five years (depending on the country) to validate a policy or correct its mistakes. The world evolves more quickly than the electoral cycle, it is necessary to take it into account and not to fear the questioning of certain orientations. This is seconded by Strobl and al, who suggest "political electoral cycles [Strobl et al., 2019] are used because voters heavily discount the past and give greater weight to recent political accomplishments. Voters may value recent events more because they are more informative and relevant for predicting the future and because it is easier to access and retrieve current information from memory. This cognitive bias leads voters to place more weight on the period right before an election." However, when a dramatic event such as COVID-19 occurs, this event acts as a stress test for democracies and pinpoint the above political behavior. The result is then an increase in the lack of confidence in elected officials and the need for better use of democratic instruments.

\section{References}

Ackerman P.L. (1988) Determinants of individual differences during skill acquisition: Cognitive abilities and information processing. Journal of Experimental Psychology: General, vol. 117, no 3, pp. 288-318.

Alazaizeh M.M., Jamaliah M.M., Mgonja J.T., Ababneh A. (2019) Tour guide performance and sustainable visitor behavior at cultural heritage sites. Journal of Sustainable Tourism, vol. 27, no 11, pp. 1708-1724.

Baaziz A., Leveille V., Dou H. (2017) Intelligence économique et Développement Durable des territoires: De la compétitivité à la coopétitivité. R2IE Revue Internationale d'Intelligence Economique, no 9, p. 55.

Berger S.L., Kouzarides T., Shiekhattar R., Shilatifard A. (2009) An operational definition of epigenetics. Genes and Development, vol. 23, no 7, pp. 781-783.

Blanchy S. (2013) Nature et Culture en Anthropologie. 1970-2010: Les sciences de l'homme en débat (eds. H. Inglebert, Y. Brailowsky), Nanterre: Presses universitaires de Paris Nanterre, pp. 317-329.

Caillé A. (2016) Eléments d’une politique convivialiste, Lormont (France): Le bord de l'eau.

Caillé A. (2018) Il faut repenser le statut et l'avenir des sciences économiques et sociales. Le Monde des Idées, 10.04.2018. Available at: https://www.lemonde.fr/idees/article/2018/04/10/alain-caille-il-faut-repenser-le-statut-et-l-avenir-dessciences-economiques-et-sociales_5283138_3232.html, accessed 12.02.2020.

Carayon B. (2003) Intelligence economique, competitivite et cohesion social, Paris: Ministère de l'Intérieur français. Available at: http://bdc.aege.fr/public/Intelligence_economique_competitivite_et_cohesion_sociale_2003.pdf, accessed 18.01.2020.

Chabot P. (2013) The philosophy of Simondon: Between technology and individuation, London: Bloomsbury Academic.

Clerc P. (2018) La culture au cour des rapports de force économiques. Diplomatie, vol. 5, pp. 32-35.

Curtis S., Fair A., Wistow J., Val D.V., Oven K. (2017) Impact of extreme weather events and climate change for health and social care systems. Environmental Health, vol. 16, no 1, art. 128. Available at: https://www.ncbi.nlm.nih.gov/pmc/articles/ PMC5773887/, accessed 29.02.2020.

D’Aveni R.A. (2012) Strategic Capitalism. The New Economic Strategy for Winning the Capitalist Cold War, New York: Mc Graw Hill.

Darbellay F. (2019) Postdisciplinarity: Imagine the future, think the unthinkable. Postdisciplinary knowledge (ed. T. Pernecky), London: Routledge, pp. 235-250.

Davezies L., Pech T. (2014) La nouvelle question Territoriale, Paris: Terra Nova Foundation. Available at: https://www.osons-astmalo.com/wp-content/uploads/2018/01/03092014_-_La_nouvelle_question_territoriale.pdf, accessed 23.02.2020.

Dawkins R. (1976) The Selfish Gene, New York: Oxford University Press.

De Rosnay J. (2018) La Symphonie du vivant, Paris: Les Liens qui Libèrent.

Dou H. (2010) Innover dans la recherche publique en France: la responsabilité sociale de la recherche (RSR) est-elle mesurée? Vie et Sciences Economiques, no 3-4, pp. 148-167.

Dou H. (2016) Innovation et industrialisation: Un enjeu pour la France. Vie sciences de lentreprise, no 1, pp. 167-189.

Dou H. (2018) Du métabolisme de l'Information à l'Intelligence Economique, R2IE Revue Internationale d'Intelligence Economique, vol. 10, no 1, pp.7-11. Available at: http://s244543015.onlinehome.fr/ciworldwide/?p=2283, accessed 12.04.2020.

Dou H., Juillet A., Clerc P. (2018) Strategic Intelligence for the Future, London: Wiley.

Dou H., Juillet A., Clerc P., (2019) L'Intelligence Economique et Stratégique dans la perspective de World3 2000. R2IE Revue Internationale d'Intelligence Economique, vol. 11, no 2, pp. 121-134.

Dou H., Juillet A., Gineys S. (2020) Les biens communs — Gouvernance éthique and COVID-19. Available at: http://s244543015. onlinehome.fr/ciworldwide/?p=2417, accessed 15.02.2020. 
Dou H., Leveillé V. (2015) Utilisation de l'information brevet pour faciliter la créativité et le développement technologique. Application au développement durable. R2IE Revue internationale d'intelligence économique, vol. 7, no 1, pp. 25-45.

Duarte A.S. (2020) A Shift in the Security Paradigm: Global Challenges: Is Europe Ready to Meet Them?, Heidelberg; New York; Dordrecht; London: Springer.

Dumont G.F. (2017) Territoires: le modèle "centre-périphérie” désuet. Outre-Terre, no 2, pp. 64-79. Available at: https://www. cairn.info/revue-outre-terre2-2017-2-page-64.htm\#, accessed 25.02.2020.

Franken S., Wattenberg M. (2019) The Impact of AI on Employment and Organisation in the Industrial Working Environment of the Future. Paper presented at the ECIAIR 2019 European Conference on the Impact of Artificial Intelligence and Robotics, 31 October - 01 November 2019, Oxford, UK.

Froese A., Mevissen N. (2020) Failure through Success: Co-construction Processes of Imaginaries (of Participation) and Group Development. Science, Technology and Human Values, vol. 45, no 3, pp. 455-487.

Göçmen Ö., Coşkun H. (2019) The effects of the six thinking hats and speed on creativity in brainstorming. Thinking Skills and Creativity, vol. 31, pp. 284-295.

Goujon D., Goyet G., Poisat J. (2011) L'université citoyenne et solidaire: Une modalité exploratoire de co-construction du développement local dans une région en reconversion. Paper presented at the 57ème congrès de l'Association Internationale des Economistes de Langue Française, Opatija (Croatia), May 23-25, 2011.

Greenwood R., Hinings C.R. (1993) Understanding strategic change: The contribution of archetypes. Academy of Management Journal, vol. 36, no 5, pp. 1052-1081. Available at: https://journals.aom.org/doi/abs/10.5465/256645, accessed 17.03.2020.

Habermas J. (1978) L’Espace public, Paris: Payot.

Hanushek E.A., Peterson P.E., Talpey L.M., Woessmann L. (2019) The achievement gap fails to close. Education Next, vol. 19, no 3, pp. 8-17.

Hashemi M.S. (2016) The effect of infrastructure, corporate culture, organizational structure and information technology on Competitive Intelligence in Organizations. Human Resource Management, vol. 3, no 3, pp. 43-50.

Hassink R., Isaksen A., Trippl M. (2019) Towards a comprehensive understanding of new regional industrial path development. Regional Studies, vol. 53, no 11, pp. 1636-1645.

Hauswedell T., Körner A., Tiedau U. (eds.) (2019) Re-mapping Centre and Periphery: Asymmetrical Encounters in European and Global Contexts, London: UCL Press.

Heurgon E. (2006) Le Développement durable, c'est enfin du bonheur!, La Tour d'Aigues (France): Edition de l'Aube.

Hirth K.G. (1996) Political economy and archaeology: Perspectives on exchange and production. Journal of Archaeological Research, vol. 4, no 3, pp. 203-239.

Holloway K., Herder M. (2019) A responsibility to commercialize? Tracing academic researchers' evolving engagement with the commercialization of biomedical research. Journal of Responsible Innovation, vol. 6, no 3, pp. $263-283$.

Iliadis A. (2013) Informational Ontology: The Meaning of Gilbert Simondon's Concept of Individuation. Communication+1, vol. 2, no 1, art. 5, pp. 1-19. Available at: https://scholarworks.umass.edu/cgi/viewcontent.cgi? article=1015\&context=cpo, accessed 15.03.2020.

Kafka K.I., Kostis P.C., Petrakis P.E. (2020) Why Coevolution of Culture and Institutions Matters for Economic Development and Growth? Perspectives on Economic Development - Public Policy, Culture, and Economic Development (eds. R.M. Yonk, V. Bobek), Chapter I, London: IntechOpen. Available at: https://cdn.intechopen.com/pdfs/70618.pdf, accessed 25.03.2020.

Kyrou A., Rumpala Y. (2019) Experiencing the collapsological plurality of science-fiction. Multitudes, vol. 3, pp. $104-112$.

Lamy J. (2012) La fabrique politique du corps: Historiographie sélective des héritages foucaldiens. Cahiers d'histoire: Le corps territoire politique, no 118, pp. 91-114. Available at: https://rechercheisidore.fr/search/resource/?uri=10670\%2F1.8bgl9g, accessed 19.01.2020.

Lamy J. (2014) Les sources libérales de la biopolitique. Cahiers d'histoire: Les libéralismes en question (XVIIIe-XXIe siècles), no 123. Available at: https://journals.openedition.org/chrhc/3509, accessed 19.01.2020.

Latour B. (1991) Nous n’avons jamais été modernes: Essai d’anthropologie symétrique, Paris: La Découverte.

Le Crosnier A. (2012) Elinor Olstrom ou la réinvention des biens communs. Le Monde Diplomatique, 14.06.2012. Available at: https://blog.mondediplo.net/2012-06-15-Elinor-Ostrom-ou-la-reinvention-des-biens-communs, accessed 05.03.2020.

Leese M. (2017) Holding the project accountable: Research governance, ethics, and democracy. Science and Engineering Ethics, vol. 23, no 6, pp. 1597-1616.

LeVeck B.L., Narang N. (2017) The democratic peace and the wisdom of crowds. International Studies Quarterly, vol. 61, no 4, pp. 867-880.

Linebaugh P. (2010) Enclosures from the bottom up. Radical History Review, vol. 108, pp. 11-27.

Loiseau E., Saikku L., Antikainen R., Droste N., Hansjürgens B., Pitkänen K., Leskinen P., Kuikman P., Thomsen M. (2016) Green economy and related concepts: An overview. Journal of Cleaner Production, no 139, pp. 361-371.

Lynch M.J., Stretesky P.B. (2017) Social Structure and Sociobiology: A Radical-Political Economic Reinterpretation. Journal of Theoretical and Philosophical Criminology, vol. 9, no 1, pp. 68-83. 
Madureira L., Castelli M., Popovič A. (2019) Design Thinking: The New Mindset for Competitive Intelligence? Impacts on the Competitive Intelligence Model. Paper presented at the 19th Portuguese Association of Information Systems Conference "Digital Disruption: Living between Data Science, IoT and ... People", 11-12 October, Lisboa, Portugal. Available at: https:// aisel.aisnet.org/capsi2019/26/, accessed 12.04.2020.

Major D.A., Kozlowski S.W. (1997) Newcomer information seeking: Individual and contextual influences. International Journal of Selection and Assessment, vol. 5, no 1, pp. 16-28.

Matray M., Poisat J. (2014) Les PTCE, une dynamique citoyenne et institutionnelle d'innovations sociales. Cahiers du Cirtes Hors - Série 4, Presses Universitaires de Louvain, pp. 1-13. Available at: https://hal-univ-lyon3.archives-ouvertes.fr/hal00992994/document, accessed 18.04.2020.

Micheli P., Wilner S.J., Bhatti S.H., Mura M., Beverland M.B. (2019) Doing design thinking: Conceptual review, synthesis, and research agenda. Journal of Product Innovation Management, vol. 36, no 2, pp. 124-148.

Neves J.P. (2011) Pour comprendre les nouvelles liaisons digitales: Le concept d'individuation chez Carl Jung et Gilbert Simondon. Sociétés, vol. 1, pp. 105-114.

Nonaka I., Toyama R., Konno N. (2000) SECI, Ba and leadership: A unified model of dynamic knowledge creation. Long Range Planning, vol. 33, no 1, pp. 5-34.

Ostrom E. (1990) Governing the Commons: The Evolution of Institutions for Collective Action (Political Economy of Institutions and Decisions), Cambridge: Cambridge University Press.

Ostrom E. (2012) La politique verte doit être impulsée de la base. Les Echos, 12.06.2012. Available at: http://archives.lesechos. fr/archives/cercle/2012/06/12/cercle_47861.htm, accessed 12.11.2019.

Revel C. (2015) Référentiel et notions clefs de l'Intelligence Economique (Rapport de la Délégation Interministérielle à l'Intelligence Economique), Paris: CDSE. Available at: https://condette.wordpress.com/2015/06/27/referentiel-et-notionsclefs-de-lintelligence-economique/, accessed 17.04.2020.

Rollot C. (2018) Dans l'Aube une centrale photovoltaïque financée et gérée par ses habitants. Le Monde Economie, 31.05.2018. Available at: https://www.lemonde.fr/economie/article/2018/05/31/dans-l-aude-une-centrale-photovoltaique-financee-etgeree-par-les-habitants_5307463_3234.html, accessed 19.05.2020.

Servigne P., Chapelle G. (2017) L'entraide, l'autre loi de la jungle, Paris: Les Liens qui Libèrent.

Simondon G. (1958). Du mode dexistence des objets techniques. Paris: Aubier-Montaigne.

Staffell I., Pfenninger S. (2018) The increasing impact of weather on electricity supply and demand. Energy, vol. 145, pp. 65-78.

Strobl D., Bäck H., Müller W.C., Angelova M. (2019) Electoral Cycles in Government Policy Making: Strategic Timing of Austerity Reform Measures in Western Europe. British Journal of Political Science (in press, first published online 08.11.2019). Available at: https://doi.org/10.1017/S0007123419000073, accessed 12.06.2020.

Verlaeten M.-P. (2010) La créativité. Available at: http://s244543015.onlinehome.fr/ciworldwide/?p=1933, accessed 04.02.2020.

Yankov Y. (2019) Human intelligence in different operations. Science. Business. Society, vol. 4, no 2, pp. 77-79.

Yun L., Zherui Y., Na G., Liang L. (2020) Situation Description Is an Important Part of Competitive Intelligence. American Journal of Information Science and Technology, vol. 4, no 2, pp. 25-29. 